\title{
Difficulties in diagnostics of polycystic ovary syndrome in adolescents - a preliminary study
}

Trudności w diagnostyce zespołu policystycznych jajników u młodzieży - badanie pilotażowe

\author{
Monika A. Milczarek, Anna M. Kucharska, Ada Borowiec
}

Department of Endocrinology and Pediatrics, Medical University of Warsaw, Children's Clinical Hospital, Warsaw, Poland

\begin{abstract}
Introduction: Polycystic ovary syndrome (PCOS) accounts for $72-84 \%$ of adult hyperandrogenism, and in the majority of cases it begins during puberty. The diagnosis based on the Rotterdam criteria seem not to be efficient enough in adolescents.

Aim of the study was the analysis of the frequency of PCOS according to Rotterdam criteria in adolescents.

Material and methods: Twenty-six girls with menstrual disorders and/or symptoms of hyperandrogenism two years after menarche were enrolled. We analysed medical history, clinical symptoms, pelvic ultrasound, and testosterone concentration (T).

Results: The study group was divided into three subgroups: with isolated cutaneous manifestation $(\mathrm{CM})$ of hyperandrogenism $(n=6)$, with isolated menstrual disorders (MD; $n=10)$, and with cutaneous manifestation and menstrual disorders (CMMD; $n=10)$. We compared total T (cut-off points: > $42 \mathrm{ng} / \mathrm{dl}$ and $>55 \mathrm{ng} / \mathrm{dl}$ ) and polycystic ovarian morphology (PCOM) occurrence. PCOM was detected in $54 \%$ of girls, with the highest proportion in the MD group (70\%). Using a testosterone cut-off point of $>42 \mathrm{ng} / \mathrm{dl}$, hyperandrogenaemia was confirmed in $81 \%$ with a preponderance of the CMMD group (90\%). Eleven patients (42\%) met all Rotterdam criteria. By more restricted criteria with a testosterone cut-off point of $>55 \mathrm{ng} / \mathrm{dl}$, hyperandrogenaemia was confirmed in $54 \%$ of patients, with the highest contribution in the CMMD group (70\%), and seven patients (27\%) met all Rotterdam criteria. Study did not show any correlation between $\mathrm{T}$ and ovarian volume $\left(p=0.695 ; \mathrm{R}_{\mathrm{s}}=0.08\right)$.

Conclusions: In our study $27 \%$ of patients suspected of PCOS met all Rotterdam criteria. The co-occurrence of symptoms increases the probability of hyperandrogenaemia.
\end{abstract}

Key words:

hyperandrogenism, menstrual disorders, hirsutism, PCOS, adolescents.

\section{Streszczenie}

Wprowadzenie: Zespół policystycznych jajników (PCOS) jest przyczyną 72-84\% hiperandrogenizmu u kobiet. Kryteria rotterdamskie wydają się jednak niewystarczające w rozpoznaniu tego zespołu u dziewcząt.

Cel pracy: Analiza częstości rozpoznawania PCOS u młodzieży na podstawie kryteriów rotterdamskich.

Materiał i metody: Do badania włączono 26 dziewcząt z zaburzeniami miesiączkowania i/lub objawami hiperandrogenizmu. Analizowano wywiad, objawy kliniczne, USG miednicy mniejszej oraz stężenie testosteronu (T).

Wyniki: Grupa badana została podzielona na 3 podgrupy: z manifestacją skórną (CM) hiperandrogenizmu $(n=6)$, z zaburzeniami miesiączkowania (MD; $n=10$ ) oraz z jednoczesnym występowaniem objawów skórnych i zaburzeń miesiączkowania (CMMD; $n=10$ ). Porównywano stężenie całkowitego T (punkty odcięcia: > 42 ng/dl i > 55 ng/dl) oraz obecność jajników policystycznych (PCOM). Obecność jajników policystycznych stwierdzono u 54\% dziewcząt, z najwyższym odsetkiem w grupie MD (70\%). Przy zastosowaniu punktu odcięcia dla $\mathrm{T}>42 \mathrm{ng} / \mathrm{dl}$ hiperandrogenemię (HA) stwierdzono u 81\% z przewagą grupy CMMD (90\%). U 11 pacjentek (42\%) stwierdzono obecność wszystkich kryteriów rotterdamskich. Stosując punkt odcięcia dla T > 55 ng/dl, HA rozpoznano u 54\% dziewcząt, również z przewagą w grupie CMMD (70\%), a tylko 7 pacjentek spełniało wszystkie kryteria (27\%). Nie wykazano korelacji między T a objętością jajników $\left(p=0,695 ; R_{s}=0,08\right)$.

Wnioski: W badaniu wyłącznie $27 \%$ pacjentek podejrzanych o PCOS spełniło wszystkie kryteria rotterdamskie. Współwystępowanie zaburzeń miesiączkowania i hirsutyzmu zwiększa ryzyko potwierdzenia hiperandrogenemii.

Słowa kluczowe:

hiperandrogenizm, zaburzenia miesiączkowania, hirsutyzm, PCOS, młodzież. 


\section{Introduction}

Polycystic ovary syndrome (PCOS) is a heterogeneous endocrine disorder that concerns $6-15 \%$ women of reproductive age [1]. It accounts for $72-84 \%$ of adult hyperandrogenism [1], but the development of PCOS usually begins during puberty. The complexity of the pathophysiology of PCOS is associated with interactions between genetic and environmental factors, which may vary in affected individuals.

The diagnosis of PCOS in adult women is based on the clinical and biochemical characteristics, known as the Rotterdam criteria, accepted by the European Society of Human Reproduction and Embryology and the American Society for Reproductive Medicine (ESHRE/ASRM 2004, 2012) [2]. They include hyperandrogenism, menstrual irregularity, and/or polycystic ovary morphology (PCOM) on ultrasound (should have either $\geq 12$ follicles measuring $2-9 \mathrm{~mm}$ in diameter or an increased ovarian volume of $>10 \mathrm{ml}$ using transabdominal visualisation) [3]. Nevertheless, the diagnosis of PCOS in adolescence may be difficult considering the possible physiological menstrual irregularity for two years after menarche and common PCOM-like features in healthy girls [4].

The overlap between normal pubertal development and characteristics of PCOS may confound an accurate diagnosis of PCOS among adolescent girls. On the other hand, ovarian androgenic function in adolescents may have a prognostic value indicating higher risk of PCOS in the future [5].

Concurrently, the diagnostic label of PCOS to an adolescent may be problematic and may result in unnecessary treatment and impose psychological distress, which by itself may be associated with several concerns including those of body image and concerns over future fertility [6]. Lack of unification of diagnostic criteria for PCOS in adolescents can make it difficult to analyse data from literature. There is no agreement concerning how to diagnose PCOS in adolescence, or whether such a diagnosis should be made before the age of 18 years $[6,7]$. The majority of authors propose diagnosing PCOS in girls who fulfil all Rotterdam criteria [7-9].

The aim of the study was an analysis of the frequency of PCOS according to Rotterdam criteria in adolescents referred to our clinic for diagnostics.

\section{Material and methods}

Data were obtained from the records of 36 girls, hospitalised in the Department of Paediatrics and Endocrinology in the period between June 2015 and July 2017, who were referred to paediatric endocrinologist because of menstrual disorders or/and symptoms of hyperandrogenism. Data were evaluated retrospectively. We conducted an analysis of patients with initial diagnosis that indicated suspicion of PCOS: oligomenorrhoea or secondary amenorrhoea, hirsutism, and/or acne. Oligomenorrhoea was defined as cycles that last longer than 35 days or occur less than eight times a year, and secondary amenorrhoea was recognised in the absence of menstruation for more than three months [1]. Both disorders were diagnosed at least two years post-menarche. Patients with adrenal hyperandrogenism and anorexia nervosa were excluded from the study group.

For further analysis 26 patients were enrolled, in whom ovarian hyperandrogenism was suspected. In enrolled patients, medical history was analysed, clinical examination and transabdominal pelvic ultrasound was performed, and testosterone concentration was assessed. The serum concentration of total testosterone was measured by Chemiluminescence Immunoassay (CLIA) using the Architect i1000SR system (Abbott, Germany). Subsequent assessment of ovarian hyperandrogenaemia was performed according to the latest recommendations of American Academy of Paediatrics (AAP 2015) as an elevation of serum testosterone $>55 \mathrm{ng} / \mathrm{dl}$ [10] and according to the study by Gambinieri et al. [11] recognising a total testosterone cut-off point above $42 \mathrm{ng} / \mathrm{dl}$. A Philips TISO.6 Ml 1.2 ultrasound was used to assess ovarian morphology. Ovarian volume $>10 \mathrm{ml}$ was recognised as PCOM [12]. Statistical analysis was performed to determine the clinical profile of young patients referred to an endocrinologist with menstrual disorders and hyperandrogenism. Statistical analysis of mean, standard deviation, and Spearman correlation was carried out using Statistica 13.1 and Microsoft Office Excel 2013 software.

\section{Results}

Presence of biochemical and ultrasound characteristics

The mean age of the enrolled patients was $17.04 \pm 1.28$ years (range 13.75-18 years old). The study group was divided into three subgroups according to their symptoms: with isolated cutaneous manifestation (CM) of hyperandrogenism $(n=6)$, with isolated menstrual disorders (MD; $n=10$ ), and with simultaneous cutaneous manifestation and menstrual disorders (CMMD; $n=10)$.

In those three groups we compared total testosterone levels and occurrence of PCOM. Each group was analysed by two cut-off points: $>42 \mathrm{ng} / \mathrm{dl}$ and $>55 \mathrm{ng} / \mathrm{dl}$.

The mean ovarian volume in the study group was 12.2 $\pm 4.76 \mathrm{ml}$ (median $11.1 \mathrm{ml}$; range 5.3-23.9 ml). Enlarged ovaries $>10 \mathrm{ml}$ (range: $11-23.9 \mathrm{ml}$ ) were detected in 54\% (14/26) of girls from the whole group. The highest proportion of patients with PCOM was in the MD group (70\%; 7/10). Similarly, in the CMMD group 60\% of patients had PCOM (6/10). In CM girls the contribution of PCOM was the lowest and was found only in one patient ( $n=17 \%)$.

In enrolled patients mean T concentration was $57.85 \mathrm{ng} / \mathrm{dl}$ \pm 19.65 (median $56 \mathrm{ng} / \mathrm{dl}$; range: 29-128 ng/dl). According to Gambinieri criteria [11], in the whole group hyperandrogenaemia was confirmed in $81 \%(21 / 26)$ of patients: $83 \%$ in the CM group, $70 \%$ in the MD group, and $90 \%$ in the CMMD group.

Using more restricted criteria proposed by AAP, only $54 \%$ $(14 / 26)$ of all patients had biochemical hyperandrogenism. Hyperandrogenaemia was confirmed in 33\% (2/6) of patients in the $\mathrm{CM}$ group, in $50 \%(5 / 10)$ of the MD group, and in $70 \%$ (7/10) of the CMMD group (Table I). 
Table I. The percentage of patients according to the clinical subgroups, testosterone concentration and presence of PCOM

\begin{tabular}{llll}
\hline Group & $T^{\star}>42 \mathrm{ng} / \mathrm{dl}$ & $\mathrm{T}>55 \mathrm{ng} / \mathrm{dl}$ & $\mathrm{PCOM}$ \\
\hline $\mathrm{CM}$ & $83 \%$ & $33 \%$ & $17 \%$ \\
$(n=6)$ & & & \\
\hline $\mathrm{MD}$ & $70 \%$ & $50 \%$ & $70 \%$ \\
$(n=10)$ & & & \\
\hline $\mathrm{CM}+\mathrm{MD}$ & $90 \%$ & $70 \%$ & $60 \%$ \\
$(n=10)$ & & &
\end{tabular}

CM - cutaneous manifestation; MD - menstrual disorders; PCOM polycystic ovarian morphology; $\mathrm{T}$ - testosterone

Table II. The percentage of patients with Rotterdam criteria according to testosterone concentration

\begin{tabular}{|c|c|c|}
\hline Group & $\begin{array}{l}\text { Testosterone } \\
>42 \mathrm{ng} / \mathrm{dl}\end{array}$ & $\begin{array}{l}\text { Testosterone } \\
>55 \mathrm{ng} / \mathrm{dl}\end{array}$ \\
\hline $\begin{array}{l}\text { At least } 2 \text { Rotterdam } \\
\text { criteria present }\end{array}$ & $\begin{array}{l}77 \% \\
(n=20)\end{array}$ & $\begin{array}{l}77 \% \\
(n=20)\end{array}$ \\
\hline $\begin{array}{l}\text { All } 3 \text { Rotterdam criteria } \\
\text { present }\end{array}$ & $\begin{array}{l}38 \% \\
(n=10)\end{array}$ & $\begin{array}{l}27 \% \\
(n=7)\end{array}$ \\
\hline
\end{tabular}

\section{Diagnosis of PCOS}

The presence of at least two of the Rotterdam criteria was found in $77 \%(20 / 26)$ of patients in the whole group. The presence of all Rotterdam criteria using adult cut-off point ( $>55 \mathrm{ng} / \mathrm{dl}$ ) applied to only seven patients, which accounted for $27 \%$ of patients. When a lower cut-off point was used (> $42 \mathrm{ng} / \mathrm{dl})$, almost $38 \%(10 / 26)$ of patients had PCOS (Table II).

\section{Correlations}

We did not find any correlation between testosterone concentration and ovarian volume $\left(p=0.695 ; R_{s}=0.08\right)$ (Fig. 1).

\section{Discussion}

Since 1990 a high dynamism of the evolution of views on PCOS diagnostics has been observed. Every year brings new suggestions for the diagnostic criteria in young women, but still there are no clear guidelines. The diagnostic path of PCOS during adolescence remains open.

The recent recommendations [13] of the International Consortium of Paediatric Endocrinology (ICPE), aiming to improve worldwide care of adolescent girls with PCOS, and the Clini-

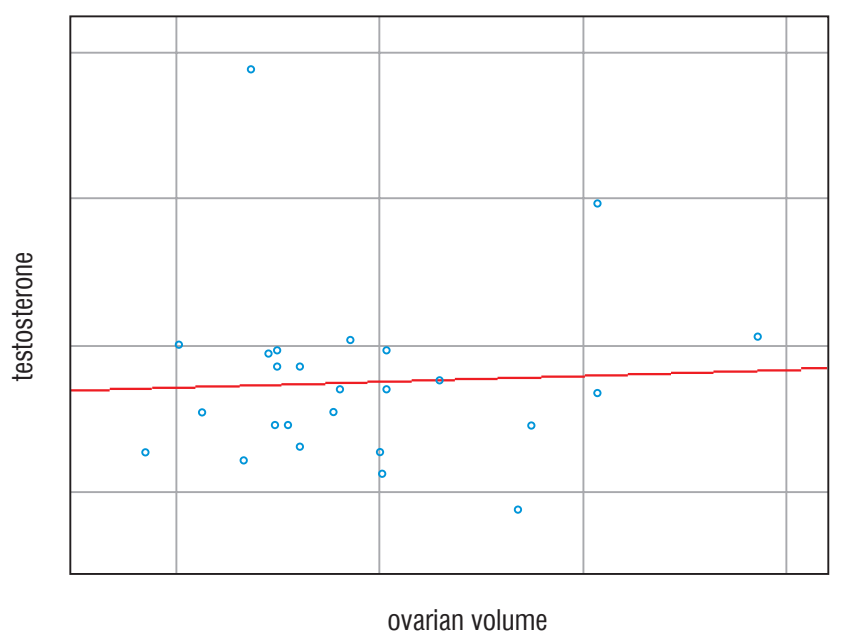

Figure 1. The correlation between testosterone concentration and ovarian volume $\left(p=0.695 ; R_{s}=0.08\right)$

cal Practice Committee for the diagnosis of PCOS in adolescents [14] presented the consensus of paediatric endocrine, obstetrics, and gynaecology, and adolescent medicine experts representing professional organisations dedicated to the care of adolescents and young women with androgen excess. They proposed guidelines based on a literature review and evidence graduation to address a series of questions regarding the diagnosis of PCOS in this age group. However, there is still no answer to the question of what criteria should be used to unambiguously diagnose PCOS in girls. Suggested criteria for the PCOS diagnosis in adolescence are divided into the following three groups [13]: 1) required: irregular menses/oligomenorrhoea; evidence of hyperandrogenism (biochemical, clinical); 2) optional: PCOM, severe cystic acne; 3) not recommended: obesity, insulin resistance, hyperinsulinaemia, biomarkers (AMH, testosterone-to-dihydrotestosterone T/DTH ratio), acanthosis nigricans. Moreover, girls must generally be two years post-menarche, and other disorders with androgen excess must be ruled out. There is a recommendation to recognise menstrual irregularity after two years of persistent oligomenorrhoea (cycle duration $>45$ days), when total and/or free testosterone concentrations and FAl (free androgen index) are elevated. The menstrual irregularities represent ovarian manifestation of hyperandrogenaemia. Approximately half of the girls with menstrual disorders without other symptoms of hyperandrogenism have elevated androgen levels [15]. This result is consistent with our findings - in the group with MD and cut-off point > $55 \mathrm{ng} / \mathrm{dl}$, hyperandrogenaemia was detected in $50 \%$ of patients. Nevertheless, the recent AAP guideline emphasise that the cycles shorter than 19 days or longer than 90 days are abnormal at any stage and should be investigated [10]. Hirsutism, which is the most common symptom of hyperandrogenaemia, may occur with no hormonal abnormalities in adolescents $[16,17]$. Also, in 
our study the majority of patients with isolated hirsutism and/or acne had no hormonal abnormalities. Hyperandrogenism is the most constant and prominent diagnostic feature of PCOS. Clinically it is diagnosed by mostly subjective assessment of cutaneous manifestations of excessive androgen activity: hirsutism, acne, and alopecia. Moderate-severe hirsutism is considered as a clinical evidence of hyperandrogenism, usually due to hyperandrogenaemia [10]. Also, moderate and severe inflammatory acne that is persistent and resistant to topical dermatological therapy should be assessed for hyperandrogenaemia before being treated by combined oral contraceptives (COC). It is possible that acne may be the only pilosebaceous manifestation of hyperandrogenaemia [18]. In the study by Hickey [9] only $18.5 \%$ of 244 girls met the Rotterdam criteria for adult women; nevertheless, the authors claim that not all of them had PCOS. In their opinion, symptoms like menstrual disorders, acne, and hirsutism should not be used for the diagnosis of PCOS in adolescents due to their great similarity to those seen in physiological puberty. In our study $30 \%$ of patients suspected of PCOS met all Rotterdam criteria for the diagnosis. This difference in results is caused by a much smaller number of enrolled patients in our study and more restricted criteria in the Hickey study [9]. According to our results, the majority of adolescents probably first report to a gynaecologist with menstrual disorders and they are rarely referred for hormonal diagnostics.

Hyperandrogenaemia should be confirmed by measurement of plasma levels of the total and free testosterone and sex hormone binding globulin (SHBG) $[1,2,14,19]$. According to Carmina et al. [7], all Rotterdam criteria should be met to diagnose PCOS in adolescents. Applying this diagnostic path, another question arises: which cut-off point for total testosterone serum concentration should be used? The Clinical Practice Committee suggest that for an assay using an extraction step, total testosterone concentration $>55 \mathrm{ng} / \mathrm{dl}$ is probably consistent with hyperandrogenism [14]. Simultaneously, they highlighted methodological problems regarding testosterone determinations, which include: insufficient assay sensitivity for low testosterone concentration and assay interference with other steroid molecules, lack of well-defined normative values, and binding testosterone with SHBG. The comparative study by Haring et al. showed that the CLIA platform gave a reasonable measurement error and yielded comparable risk associations, providing little support to measure TT concentrations in men from the general population exclusively by LC-MS/MS [7, 14, 20, 21]. Hickey et al. [9] noted that there is no internationally agreed normal range for free testosterone or FAl. Gambineri et al., in their study of 519 girls, defined hyperandrogenism as total testosterone concentration > $42 \mathrm{ng} / \mathrm{dl}$ using LC-MS/MS assay. In their study only $4 \%$ of patients could be diagnosed with PCOS. Most of the study group (17\%) presented with iso- lated clinical features of hyperandrogenism (mainly hirsutism), $10 \%$ had isolated menstrual irregularities, and only $7 \%$ had hyperandrogenaemia in laboratory tests [11]. In our study the frequency of hyperandrogenaemia at a testosterone concentration above $42 \mathrm{ng} / \mathrm{dl}$ appears to be vetted. It seems that the more appropriate diagnostic criterion for adolescents is testosterone serum concentration $>55 \mathrm{ng} / \mathrm{dl}$, as used in adults.

The most recent global update [13] on adolescent PCOS summarised that most recommendations advocate utilisation of high-quality liquid chromatography/tandem mass spectrometry (LC-MS/MS) to measure testosterone concentration. Until the LC-MS/MS technology is universally available, high-quality RIA (radioimmunoassay) with extraction and chromatography should be used. Also, they emphasised that due to variability in the results of testosterone assays and limited data on the normal development fluctuations in testosterone levels during adolescence, no clear cut-off points can be established. Available guidelines suggest that total testosterone concentrations $>55 \mathrm{ng} / \mathrm{dl}(1.91 \mathrm{nmol} / \mathrm{l})$ are probably consistent with hyperandrogenism [13].

PCOM is a common image of ovaries during puberty, and in asymptomatic girls it should not be considered as evidence for PCOS. According to research studies of Dewailly et al. (2014), PCOM could be found in 30\% of normal young women $[12,22]$. Also, in the study conducted by Codner et al. PCOM was found in $40 \%$ of healthy girls two years postmenarche, in 35\% three years post-menarche, and in 33.3\% four years post-menarche without the occurrence of abnormal ovulation or metabolic disorders associated with PCOS [4]. Ovarian volume $>10 \mathrm{~cm}^{3}$, according to Rotterdam criteria, in abdominal ultrasonography during adolescence is a more reliable parameter of PCOM than the follicle count [2]. Ibaniez et al. recommend not using follicle counts to establish PCOM in adolescents. They suggest considering enlarged ovaries with the volume above $12 \mathrm{~cm}^{3}$ until further investigation is conducted [13]. Nonetheless, transabdominal ultrasound (TA USG) is a subjective evaluation depended on the investigator's experience. In adolescents TA USG is not very precise, and as a PCOS criterion it may be unnecessary [13]. Hickey et al. concurred that ultrasound imaging caused overdiagnosis of the syndrome in their study [9].

\section{Conclusions}

In our study only $27 \%$ of patients suspected of PCOS met all Rotterdam criteria for the diagnosis. Co-occurrence of menstrual disorders and hirsutism increases the probability of hyperandrogenaemia. According to our data, PCOM does not have great value for adolescent PCOS diagnostics. 


\section{References}

1. Norman RJ, Dewailly $\mathrm{D}$, Legro RD, et al. Polycystic ovary syndrome. Lancet 2007; 370: 685-697.

2. Fauser BC, Tarlatzis RW, Rebar RS, et al. Consensus on women's health aspects of polycystic ovary syndrome (PCOS): the Amsterdam ESHRE/ASRM-Sponsored 3rd PCOS Consensus Workshop Group. Fertil Steril 2012; 97: 28-38.e25.

3. Barber TM, Alvey C, Greenslade T, et al. Patterns of ovarian morphology in polycystic ovary syndrome: a study utilizing magnetic resonance imaging. Eur Radiol 2010; 20: 1207-1213.

4. Codner E, Villarroel C, Eyzaguirre FC, et al. Polycystic ovarian morphology in postmenarchal adolescents. Fertil Steril 2011; 95: 702-706.e1-2.

5. Rosenfield RL, Ehrmann DA, Littlejohn E. Adolescent polycystic ovary syndrome due to functional ovarian hyperandrogenism persists into adulthood. J Clin Endocrinol Metab 2015; 100: 1537-1543.

6. Hardy T, Norman RJ. Diagnosis of adolescent polycystic ovary syndrome. Steroids 2013; 78: 751-754.

7. Carmina E, Oberfield SE, Lobo RA. The diagnosis of polycystic ovary syndrome in adolescents. Am J Obstet Gynecol 2010; 203: 201.e1-205.e.

8. Rackow BW. Polycystic ovary syndrome in adolescents. Curr Opin Obstet Gynecol 2012; 24: 281-287.

9. Hickey M, Sloboda DM, Atkinson HC, et al. The relationship between maternal and umbilical cord androgen levels and polycystic ovary syndrome in adolescence: a prospective cohort study. J Clin Endocrinol Metab 2009; 94: 3714-3720.

10. Rosenfield RL. The diagnosis of Polycystic Ovary Syndrome in adolescents. Pediatrics 2015; 136: 1154-1165.

11. Gambineri A, Fanelli F, Prontera O, et al. Prevalence of hyperandrogenic states in late adolescent and young women: epidemiological survey on italian high-school students. J Clin Endocrinol Metab 2013; 98: 1641-1650.

12. Dewailly D, Lujan ME, Carmina E, et al. Definition and significance of polycystic ovarian morphology: a task force report from the An- drogen Excess and Polycystic Ovary Syndrome Society. Hum Reprod Update 2014; 20: 334-352.

13. Ibaniez L, Oberfield SE, Witchel S, et al. An International Consortium Update: Pathophysiology, Diagnosis, and Treatment of Polycystic Ovarian Syndrome in Adolescence. Horm Res Paediatr 2017; 88: 371-395.

14. Witchel SF, Oberfield S, Rosenfield RL, et al. The diagnosis of polycystic ovary syndrome during adolescence. Horm Res Paediatr 2015; 83: 376-389.

15. Porcu E, Venturoli S, Magrini O, et al. Circadian variations of luteinizing hormone an have two different profiles in adolescent anovulation. J Clin Endocrinol Metab 1987; 65: 488-493.

16. Escobar-Morreale HF, Carmina E, Dewailly D, et al. Epidemiology, diagnosis and management of hirsutism: a consensus statement by the Androgen Excess and Polycystic Ovary Syndrome Society. Hum Reprod Update 2012; 18: 146-170.

17. Deplewski D, Rosenfield RL. Role of hormones in pilosebaceous unit development. Endocr Rev 2000; 21: 363-392.

18. Lucky AW, Biro FM, Daniels SR, et al. The prevalence of upper lip hair in black and white girls during puberty: a new standard. J Pediatr 2001; 138: 134-136.

19. Carmina E, Rosato F, lanni A, et al. Extensive clinical experience: relative prevalence of different androgen excess disorder in 950 women referred because of clinical hyperandrogenism. J Clin Endocrinol Metab 2006; 91: 2-6.

20. Haring R, Baumeister SE, Nauck M, et al. Testosterone and cardiometabolic risk in the general population - the impact of measurement method on risk associations: a comparative study between immunoassay and mass spectrometry. Eur J Endocrinol 2013; 169: 463-470.

21. Rosner W, Auchus RJ, Azziz R, et al. Position statement: utility, limitations, and pitfalls in measuring testosterone: an Endocrine Society position statement. J Clin Endocrinol Metab 2007; 92: 405-413.

22. Villarroel C, Merino PM, Lopez P, et al. Polycystic ovarian morphology in adolescents with regular menstrual cycles is associated with elevated anti-Mullerian hormone. Hum Reprod 2011; 26: 2861-2868. 